\author{
Лойко Валерія Вікторівна, \\ доктор економічних наук, дочент, \\ профресор кафедри фінансів та економіки, \\ Київський університет імені Бориса Грінченка, \\ м. Київ, Україна \\ ORCID iD 0000-0003-3248-1585 \\ e-mail:v.loiko@kubg.edu.ua \\ Маляр Станіслав Анатолійович, \\ здобувач ступеня магістр, \\ Київський університет імені Бориса Грінченка, \\ м. Київ, Україна \\ e-mail:st.malyar@gmail.com
}

\title{
ЕКОНОМІКО-ПРАВОВІ АСПЕКТИ ІННОВАЦІЙНОГО РОЗВИТКУ ЖИТЛОВОГО ФОНДУ УКРАЇНИ
}

\begin{abstract}
Анотація. У статтірозглянуто економіко-правові аспекти інновачійного розвитку житлового фонду України в умовах євроінтеграчійного розвитку економіки України. Сучасний процес реформування житлового фонду України пов'язаний із створенням об'єднань співвласників багатоквартирних будинків (ОСББ), які є неприбутковими організаціями і діють у рамка, визначених законодавством України. На теперішній час конкретний перелік суб'єктів управління житловим фондом $\epsilon$ відсутнім. За проведеним аналізом нормативно-законодавчих актів, що регулюють відносини у сфері житлового господарства, можна виділити наступні суб'єкти господарювання: власник житлового будинку або житлового комплексу, співвласник багатоквартирного будинку, об'єднання співвласників багатоквартирного будинку, житлово-комунальні підприємства, управитель, виконавещь комунальної послуги, споживач, виконавець. Серед учасників відносин у срері надання послуг з управління житлом особливо слід виокремити таких суб'єктів, як споживач, виробник та виконавець житловокомунальних послуг. Співвласники багатоквартирного будинку можуть здійснювати управління житловим фондом самостійно або безпосередньо ухвалюючи певні рішення на зборах. Прочес управління житловим фондом характеризується наявністю ієрархії рівнів управління та багатофункціональністю. Узагальнено у хронологічній послідовності зміни у законодавчих та нормативних актах України щодо управління об'єктами житлового фонду, котре дозволило виявити, що на ефективність управління об'єктами житлового фонду впливає недосконалість нормативно-правової бази України. Сучасне економічне державне регулювання житлово-комунальної сфери здійснюється за рахунок податкової, інвестиційної, бюджетної, цінової політики та цінового регулювання. Процес управління житловим фондом, зокрема ОСББ, потребує аналізу методів управління, що застосовуються в теперішній час, та напрацювання досвіду із застосування інноваційних методів, які забезпечать достатній рівень управлінської безпеки. Виділено фактори забезпечення управлінської безпеки житлової срери. Вбачається потреба у збільшенні обсягів приватно-державного співфінансування програм реконструкиії, реставрації, проведення капітальних ремонтів, технічного переоснащення спільного майна у багатоквартирних будинках та реалізації енергоефективних заходів у житлових будинках міст та сіл України.
\end{abstract}

Ключові слова: Україна, житловий фонд, стан, розвиток, інновачії, законодавство, регулювання, нормативно-правові акти, есективність. 


\section{ВСТУП}

Постановка проблеми. Подолання проблем низької ефективності діяльності житлово-комунального господарства, повільного узгодження нормативно-законодавчих актів, дефіциту бюджетних коштів на розвиток житлового фонду, створення конкурентного середовища у сфері надання комунальних послуг потребує дослідження економіко-правових аспектів розвитку житлового фонду на основі інновацій та розробки науково обгрунтованих заходів щодо підвищення ефективності його функціонування.

Аналіз останніх досліджень і публікацій. Питанням розробки методичних і практичних аспектів фінансово-економічних питань реформування житлово-комунального господарства приділено увагу в працях вчених: О.В. Димченко, К.С. Савенко, О.В. Твердь, О.Є. Кущ, B.M. Філатов та інших науковців. В умовах швидких змін економічної ситуації в країні та зважаючи на зовнішні дестабілізаційні фактори, необхідно доповнювати праці науковців сучасними дослідженнями щодо реформування фінансово-економічних умов розвитку житлового господарства, приділити увагу чинникам, що впливають на стабільність та ефективність, зокрема створення ОСББ.

Мета статті полягає у дослідженні сучасного стану економічного і нормативно-правового забезпечення розвитку житлового фонду України та окреслення найбільш ефективних напрямів його інноваційного розвитку.

\section{РЕЗУЛЬТАТИ ДОСЛІДЖЕННЯ}

Сучасний процес реформування житлово-комунального господарства в Україні пов'язаний із створенням об'єднань співвласників багатоквартирних будинків (ОСББ). грунтовно сутність ОСББ визначено Проектом Житлового кодексу України, де передбачено, що об'єднання співвласників багатоквартирного будинку є неприбутковою організацією, утвореною відповідно до закону та з урахуванням цього кодексу власниками (співвласниками) багатоквартирного будинку (будинків) з метою спільного користування, володіння та розпорядження об'єктами спільної власності в багатоквартирному будинку (будинках), і не має на меті отримання прибутку для подальшого розподілу між членами об'єднання, за винятком спрямування

отриманого прибутку на утримання та забезпечення експлуатації спільного майна у багатоквартирному будинку (будинках) [1, ст. 56].

Фінансові ресурси $є$ абсолютно ліквідним активом, що дозволяє при належному використанні ефективно здійснювати господарську діяльність. Відповідно фінансова діяльність комунальних підприємств, ОСББ містить процеси, пов'язані із забезпеченням руху грошових коштів, зокрема: підтримка ліквідності, платоспроможності, незалежності, створення умов подальшого розвитку, що залежить від структури капіталу, витрат суб'єкта ринку й у сукупності сприяє досягненню основних цілей функціонування. Варто також враховувати, що ризики, пов'язані з цим за своїми негативними наслідками відносяться до категорії найбільш небезпечних за своїми наслідками. Дослідження фінансового стану більшості ОСББ продемонструвало, що збільшення частки матеріальних витрат та нестача фінансово-інвестиційних ресурсів $\epsilon$ першочерговою проблемою комунальних підприємств та ОСББ через неможливість застосування якісних матеріалів, оновлення технологічного обладнання, залучення інновацій та поліпшення кадрового складу [2,3].

У житловій сфері міста Києва спостерігаються тенденції зростання обсягів будівництва та введення в експлуатацію нових будинків, як правило, багатоповерхових. Проте зберігаються і проблеми старого та аварійного житлового фонду. У силу різних причин, у тому числі і недостатнього рівня фінансування, питома вага аварійного та старого житла із ріку у рік зростає. Таким чином ми маємо дві протилежні проблеми у житловому фонді країни: з одного боку зростання обсягів введення в експлуатації нового житлового фонду, а з іншого нарощування темпів старіння та збільшення аварійного фонду. Це протиставлення двох різних проблем збільшує обсяг завдань 3 управління житловим фондом. Управління державним та комунальним житловим фондом здійснювалось житлово-експлуатаційними організаціями, які діяли на основі господарського розрахунку. Вони зберігаються і зараз, але в меншої кількості. Управляти численними житлово-експлуатаційними організаціями було важко і неефективно. Потрібно зауважити, що до 90-х років минулого століття у державній власності перебував майже весь житловий фонд. Держава виступала як замовник будівництва, інвестор, проектувальник житла, забезпечувала експлуатацію і була власником житлового фонду. У житловому секторі перехід від державної до приватної власності відбувся із прийняттям Закону «Про власність в СРСР» від 6 березня 1990 року № 1305-1 було законодавчо закріплено перехід України до зміни форм власності та ліквідацію безроздільного панування державної власності. Закон «Про 
приватизацію державного житлового фонду», від 19 червня 1992 року № 2482-XII можна вважати початком ринкових перетворень саме у житловому секторі України [4].

У Господарському кодексі України учасниками відносин у сфері господарювання виділено наступних учасників відносин: споживачі, суб'єкти господарювання, органи державної влади та органи місцевого самоврядування, громадські організації, окремі громадяни, інші організації, що виступають засновниками суб'єктів господарювання чи здійснюють щодо них організаційно-господарські повноваження на основі відносин власності [5, ст. 2]. Учасниками господарських відносин у сфері житлово-комунального господарства відповідно до Закону України «Про житлово-комунальні послуги» $є$ органи виконавчої влади та місцевого самоврядування, власники, виробники, виконавці та споживачі житлово-комунальних послуг [6, ст. 3].

Проте на теперішній час конкретний перелік суб'єктів управління житловим фондом $€$ відсутнім. За проведеним аналізом нормативно-законодавчих актів, що регулюють відносини у сфері житлового господарства, можна виділити наступні суб’єкти господарювання:

1. Власник житлового будинку або житлового комплексу.

2. Співвласник багатоквартирного будинку.

3. Об’єднання співвласників багатоквартирного будинку.

4. Житлово-комунальні підприємства.

5. Управитель.

6. Виконавець комунальної послуги.

7. Споживач.

8. Виконавець.

Доцільно серед учасників відносин у сфері надання послуг з управління житлом особливо слід виокремити таких суб’єктів, як споживач, виробник та виконавець житлово-комунальних послуг.

Споживач - фізична чи юридична особа, яка отримує або має намір отримати житловокомунальну послугу [6, ст. 1].

Серед споживачів - фізичних осіб визначальну роль, на нашу думку, відіграють мешканці, до яких належать власники, співвласники, наймачі, орендарі окремих житлових і нежитлових приміщень, які проживають у будинку. Споживач зобов'язаний укласти договір на надання житлово-комунальних послуг, підготовлений виконавцем на основі типового договору, а також оплачувати житлово-комунальні послуги у строки, встановлені договором або законом.
Виконавець комунальної послуги - суб'єкт господарювання, який виробляє або створює житлово-комунальні послуги [6, ст. 1]. Виробник зобов'язаний укласти договір з виконавцем або споживачем про умови надання житловокомунальних послуг та виробити ці послуги відповідно до умов договору, стандартів, нормативів, норм і правил.

Виконавець зобов'язаний забезпечувати своєчасність та відповідну якість житлово-комунальних послуг згідно із законодавством та умовами договору, в тому числі шляхом створення систем управління якістю відповідно до національних або міжнародних стандартів. Виконавцем послуг з управління житловим фондом може бути суб'єкт господарювання, з яким досягнуто згоди про надання таких послуг та укладено відповідний договір. Однак в Україні і нині, незважаючи на дискусії про формування конкурентного середовища в житлово-комунальному господарстві, майже весь житловий фонд перебуває на балансі житлово-комунальних підприємств, які визначені виконавцями послуг з утримання об’єктів житлового фонду.

Відповідно до статті 14 Податкового кодексу України житлово-комунальні підприємства це суб’єкти господарювання, які безпосередньо виробляють, створюють та/або надають житлово-комунальні послуги [7, ст. 14]. Ці підприємства укладають договори від імені мешканців з усіма суміжними комунальними службами, деякі роботи виконують самостійно. Організаційні принципи роботи житловоексплуатаційних підприємств є застарілими і це свідчить про необхідність реформування системи управління житловим фондом, демонополізації ринків попиту і пропозиції на житлово-комунальні послуги, упровадження належної системи договірних відносин та підготовки і залучення професійних управителів у цю сферу.

У 1996 р. Верховною Радою України прийнято основний закон держави - Конституцію України. В статті 42 Конституції України, законодавець визначив, що кожен має право володіти, користуватися і розпоряджатися своєю власністю, результатами своєї інтелектуальної, творчої діяльності. В зазначеній статті відображено норму, що ніхто не може бути протиправно позбавлений права власності. Право приватної власності $€$ непорушним [8]. Узагальнення змін у законодавчих та нормативних актах України щодо управління об’єктами житлового фонду наведено у хронологічній послідовності у табл. 1. 


\section{РЕЗУЛЬТАТИ УЗАГАЛЬНЕННЯ ЗМІН У ЗАКОНОДАВЧИХ ТА НОРМАТИВНИХ АКТАХ УКРАЇНИ ЩОДО УПРАВЛІННЯ ОБ’ЄКТАМИ ЖИТЛОВОГО ФОНДУ У ХРОНОЛОГІЧНІЙ ПОСЛІДОВНОСТІ}

\begin{tabular}{|c|c|}
\hline Джерело & Сутність закріпленої норми права \\
\hline Конституція України (1996) [8] & $\begin{array}{l}\text { Кожен має право володіти, користуватися і розпоряджатися } \\
\text { своєю власністю, результатами своєї інтелектуальної, творчої } \\
\text { діяльності (стаття 42). }\end{array}$ \\
\hline $\begin{array}{l}\text { «равила та порядок розподілу території } \\
\text { житлового кварталу (мікрорайону)» за- } \\
\text { тверджені Наказом Держкомбуду Украї- } \\
\text { ни № } 228 \text { від } 16.09 .1999 \text { р. (діяли до } 2005 \\
\text { р., на теперішній час альтернативного до- } \\
\text { кументу не прийнято) }\end{array}$ & $\begin{array}{l}\text { Визначають юридичні, містобудівні, технічні правила і плану- } \\
\text { вальний механізм встановлення меж земельних ділянок в існу- } \\
\text { ючій і новій багатоквартирній забудові на основі затвердженої } \\
\text { містобудівної документації у відповідності з чинним законодав- } \\
\text { ством і державними нормами з метою розподілу вказаних тери- } \\
\text { торій на окремі земельні ділянки, які знаходяться у колектив- } \\
\text { ній (приватній, спільній приватній) власності та забезпечення } \\
\text { реєстрації прав власників житлових будинків на землю і нерухо- } \\
\text { ме майно. }\end{array}$ \\
\hline $\begin{array}{l}\text { Рішення Київської міської ради від } \\
29.11 .2001 \text { № 151/1585 «Про затверджен- } \\
\text { ня переліку нежитлових будівель кому- } \\
\text { нальної власності територіальної грома- } \\
\text { ди міста Києва» (2001) [9] }\end{array}$ & $\begin{array}{l}\text { Затверджено перелік нежитлових будівель комунальної влас- } \\
\text { ності територіальної громади міста Києва. }\end{array}$ \\
\hline $\begin{array}{l}\text { Рішення Київської міської ради від } \\
27.12 .2001 \text { № 208/1642 «Про формування } \\
\text { комунальної власності територіальних } \\
\text { громад районів м. Києва» (2001) [10] }\end{array}$ & $\begin{array}{l}\text { Всі житлові будинки в місті Києві були віднесені до комунальної } \\
\text { власності територіальної громади міста Києва }\end{array}$ \\
\hline $\begin{array}{l}\text { Закон України «Про об’єднання співвлас- } \\
\text { ників багатоквартирного будинку» } \\
(2002)[11]\end{array}$ & $\begin{array}{l}\text { Надано механізм самостійного управління своїм спільним май- } \\
\text { ном через створення об’єднання співвласників. Надається мож- } \\
\text { ливість створити об’єднання, взяти будинок або цілісний май- } \\
\text { новий комплекс на баланс і не лише обслуговувати його, а й } \\
\text { розпоряджатися спільною сумісною власністю. }\end{array}$ \\
\hline $\begin{array}{l}\text { Постанова КМУ № } 1521 \text { від } 11 \text { жовтня } \\
2002 \text { р.Про реалізацію Закону України } \\
\text { «Про об'єднання співвласників багато- } \\
\text { квартирного будинку» (2002) [12] }\end{array}$ & $\begin{array}{l}\text { Порядок передачі житлового комплексу або його частини з ба- } \\
\text { лансу на баланс. }\end{array}$ \\
\hline Цивільний кодекс України (2003) [13] & $\begin{array}{l}\text { Регулює особисті немайнові та майнові відносини (цивільні від- } \\
\text { носини), засновані на юридичній рівності, вільному волевияв- } \\
\text { ленні, майновій самостійності їх учасників. Визначає що окреме } \\
\text { приміщення в житловому будинку, придатне для постійного про- } \\
\text { живання, є квартирою. Приміщення загального користування } \\
\text { (горища, підвали, колясочні) та нежитлові приміщення є спіль- } \\
\text { ною сумісною власністю співвласників квартир (стаття 382). }\end{array}$ \\
\hline $\begin{array}{l}\text { Закон України «Про особливості здійс- } \\
\text { нення права власності в багатоквартир- } \\
\text { ному будинку» (2015) [14] }\end{array}$ & $\begin{array}{l}\text { Процедура прийняття рішень щодо розпорядження спільною } \\
\text { сумісною власністю співвласників багатоквартирного будинку } \\
\text { була удосконалена. }\end{array}$ \\
\hline $\begin{array}{l}\text { Закон України «Про місцеве самовряду- } \\
\text { вання в Україні» [15] }\end{array}$ & $\begin{array}{l}\text { До виключної компетенції місцевих рад віднесено вирішення на } \\
\text { сесійних засіданнях відповідно до закону питань регулювання зе- } \\
\text { мельних відносин. Норми Закону надають можливість ОСББ, що } \\
\text { діють в місті Києві, звернутися до Київської міської ради та отри- } \\
\text { мати у власність чи постійне користування земельну ділянку, що є } \\
\text { прибудинковою територією (така можливість існувала до } 2005 \text { р.). }\end{array}$ \\
\hline
\end{tabular}




\begin{tabular}{|c|c|}
\hline Джерело & Сутність закріпленої норми права \\
\hline $\begin{array}{l}\text { Рішення Київської міської ради } \\
\text { № } 780 / 1784 \text { від } 22 \text { грудня } 2016 \text { р. «Про за- } \\
\text { твердження Положення про співфінан- } \\
\text { сування реконструкції, реставрації, } \\
\text { проведення капітальних ремонтів, тех- } \\
\text { нічного переоснащення спільного май- } \\
\text { на у багатоквартирних будинках міста } \\
\text { Києва» [16] }\end{array}$ & $\begin{array}{l}\text { Поширюється на будинки, які експлуатуються більше десяти } \\
\text { років, та передбачає співфінансування робіт у розмірі } 30 \text { \% очіку- } \\
\text { ваної вартості робіт за рахунок коштів співвласників багатоквар- } \\
\text { тирного будинку та решти вартості робіт (виходячи з остаточної } \\
\text { вартості робіт, визначеної згідно з абзацом другим пункту } 6 \text { цьо- } \\
\text { го Положення) - за рахунок коштів бюджету міста Києва. }\end{array}$ \\
\hline $\begin{array}{l}\text { Про житлово-комунальні послуги: За- } \\
\text { кон України від 07.06.2018 № 2454-VIII. } \\
\text { (2018) [6] }\end{array}$ & $\begin{array}{l}\text { Предметом регулювання цього Законує відносини, що виникають } \\
\text { у процесі надання споживачам послуг з управління багатоквар- } \\
\text { тирним будинком, постачання теплової енергії, постачання га- } \\
\text { рячої води, централізованого водопостачання, централізованого } \\
\text { водовідведення та поводження з побутовими відходами, а також } \\
\text { відносини, що виникають у процесі надання послуг з постачання } \\
\text { та розподілу електричної енергії і природного газу споживачам } \\
\text { у житлових, садибних, садових, дачних будинках. }\end{array}$ \\
\hline
\end{tabular}

Джерело: складено авторами за даними [6, 8-16]

У Законі України «Про об'єднання співвласників багатоквартирного будинку», законодавець надав співвласникам багатоквартирного будинку механізм самостійного управління своїм спільним майном через створення об'єднання співвласників багатоквартирного будинку або ОСББ. За цим законом, співвласникам багатоквартирного будинку надається можливість створити об'єднання, взяти будинок або цілісний майновий комплекс на баланс і не лише обслуговувати його, а й розпоряджатися спільною сумісною власністю [11]. Разом з тим, в зазначеному законі було допущено низку прогалин, що стали причиною формування у людей негативного ставлення до ОСББ. Зокрема, у невеликих за площами багатоквартирних будинках стали частими випадки порушення майнових прав співвласників недобропорядним керівництвом ОСББ. Для створення ОСББ ініціативна група мала провести збори, на яких відповідне рішення приймали не більше ніж 50 \% співвласників. Кожен співвласник мав один голос не залежно від того, яка частка власності в будинку йому належить. На нашу думку, ця норма закону прямо суперечила Цивільному кодексу України та була не логічною взагалі. Оскільки законодавець раніше визначив, що власність зобов'язує, і весь час співвласники сплачували кошти на утримання будинку пропорційно площі належної їм квартири, то і кількість голосів на загальних зборах, при створенні ОСББ, вони 6 повинні мати пропорційну площі належним їм житловим та нежитловим приміщенням.

Співвласники багатоквартирного будинку можуть здійснювати управління житловим фондом самостійно - або безпосередньо ухвалюючи певні рішення на зборах і виконуючи ïx за взаємною згодою, або через створення для управління спільним майном юридичної особи - об'єднання співвласників багатоквартирного будинку (ОСББ) - i надання їй відповідних повноважень. Однак співвласники або ОСББ не $є$ управителями у прямому розумінні. Щодо об'єднання співвласників багатоквартирного будинку управління належить розглядати як діяльність ОСББ для досягнення мети його створення, щодо співвласників - як невід’ємну від права власності функцію. Якщо ж управління здійснює сторонній суб'єкт господарювання, то його діяльність вже стає послугою. Враховуючи наведене, на думку дослідників [2, с. 12], «управитель» - це суб'єкт господарювання, який надає комплексну послугу з управління.

Співвласники повинні бути зацікавлені у підтриманні та поліпшенні технічного стану своїх будинків, утриманні в належному стані прибудинкових територій та розміщених на ній об'єктів благоустрою, а також у безпечному та комфортному проживанні мешканців у цьому житлі, забезпеченні ї житлово-комунальними послугами відповідно до стандартів, нормативів, норм, порядків і правил. Процес управління житловим фондом характеризується наявністю ієрархії рівнів управління та багатофункціональністю.

У теперішній час всі об'єкти житлового господарства України знаходяться у приватній або комунальній власності. Функція управління неринковим сектором повинна бути забезпечена засобами та механізмами здійснення приватно-державного партнерства. На ефективності управління об'єктами житлового фонду впливає недосконалість нормативно-правової бази України. 
Адміністративне державне регулювання функціонування сфери житлово-комунального господарства передбачає використання сили державної влади і $€$ інструментами прямого впливу. Державне регулювання у житловому секторі економіки країни передбачає здійснення державного моніторингу за цінами природних монополістів, встановлення норм і стандартів, які висуваються до робіт і послуг у житлово-комунальній сфері, надання субсидій соціально незахищеним верствам населення, створення нормальних побутових умов для проживання мешканців. Адміністративними інструментами державного регулювання житлового сектору економіки є наступні: ліцензіі, стандарти, квоти, нормативи, норми, які затверджуються правовими актами виконавчих органів влади та обмежують чи нормують окремі види діяльності у комунальному господарстві.

Економічне державне регулювання житлово-комунальної сфери здійснюється за ра- хунок податкової, інвестиційної, бюджетної, цінової політики та цінового регулювання. у межах бюджетної політики державне регулювання здійснюється за рахунок перерозподілу бюджетних коштів державного та місцевого бюджетів у частині реалізації і фінансування загальнодержавних та регіональних програм розвитку житлової сфери.

Вітчизняний досвід свідчить про типову бюрократизацію системи управління для більшості організацій та надмірний рівень витрат пов'язаний з цим, що суттєво обмежує можливість застосування управлінського інструментарію на практиці. Процес управління житловим фондом, зокрема ОСББ, потребує аналізу методів управління, що застосовуються, та напрацювання досвіду із застосування інноваційних методів, які забезпечать достатній рівень управлінської безпеки.

Основні фактори управлінської безпеки житлової сфери представлено на рис. 1.

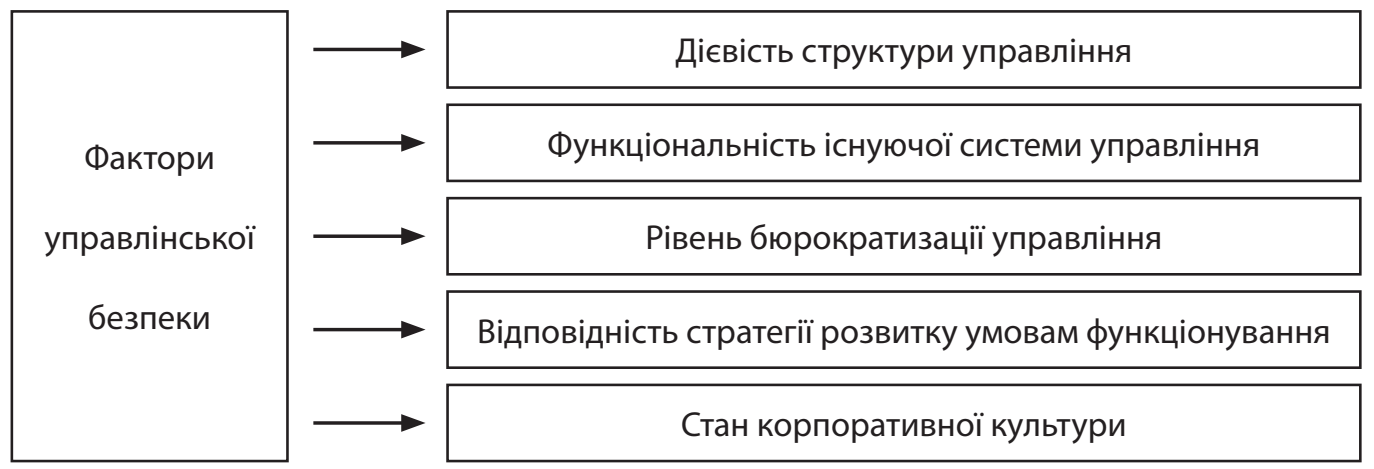

Puc. 1. Фактори управлінської безпеки житлової сфери (авторська розробка)

В економічній літературі можна виділити багато спроб побудови системи та процедури проведення діагностики економічної безпеки на рівні комунального підприємства або ОСББ. Кожен із цих методів має власні переваги відповідно до сфери застосування. SWOT-aналіз дозволяє використовувати можливість визначення основних загроз і слабких сторін об'єктів економіки для оцінки економічної безпеки. SPACE-аналіз можна застосовувати для первинної оцінки конкурентної позиції досліджуваного об’єкту на ринку, що дозволяє визначити стан його економічної безпеки. STEP-аналіз надає можливість оцінити зовнішню економічну ситуацію, яка впливає на господарську діяльності об’єкта економіки та рівень його економічної безпеки. Оскільки цей метод має чітко спрямовану зовнішню орієнтацію, його результат може розглядатися як оцінка рівня конкурентного становища підприємства на ринку.
Основним недоліком перелічених методів $\epsilon$ ïх експертний характер. Залучення до роботи експертів може вплинути на об'єктивність оцінки та відзначається високим рівнем суб'єктивізму. Відтак застосування їх пов'язано з ризиком неповного врахування впливу факторів на економічну безпеку досліджуваного об’єкту. Разом 3 тим, намагання охопити якомога більше факторів призводить до надмірної деталізації, що перешкоджатиме адекватно сприймати інформацію та проводити розробку обгрунтованих управлінських рішень. Але не можна заперечувати доцільність застосування цих методів у сфері діагностики рівня економічної безпеки об'єктів економіки як допоміжний інструментарій.

Для підвищення ефективності управління об'єктами житлового фонду доцільно органам влади та місцевого самоврядування міст та сіл України розробити та систематично проводити заходи, спрямовані на підвищення правової культури населення, виховання у громадян 
відповідальності за спільну сумісну власність. Досвід міста Києва в модернізації об'єктів житлового фонду та формування свідомості громадян, як відповідальних співвласників багатоквартирних будинків є позитивним і може слугувати прикладом для формування загальнодержавної політики.

\section{ВИСНОВКИ ТА ПЕРСПЕКТИВИ ПОДАЛЬШИХ ДОСЛІДЖЕНЬ}

Зі змінами в українському законодавстві щодо управління багатоквартирними будинками все гострішим є питання відповідальності кожного зі співвласників за стан об'єктів житлового фонду. Вбачається потреба у збільшенні обсягів приватно-державного співфінансування програм реконструкції, реставрації, проведення капітальних ремонтів, технічного переоснащення спільного майна у багатоквартирних будинках та реалізації енергоефективних заходів у житлових будинках міст та сіл України, в яких створені об'єднання співвласників багатоквартирних будинків, а також у кооперативних будинках. Активізація просвітницької діяльності серед громадян щодо участі у про- грамах розвитку житлового фонду дозволить охопити більшу кількість об’єктів житлового фонду. Доцільно стимулювати створення ОСББ через механізми відшкодування із бюджету міста адміністративних витрат на підготовку документації, утворення і реєстрацію. Доцільно запроваджувати цільові програми щодо поліпшення житлового фонду та проведення енергоефективних заходів на умовах співфінансування із мешканцями багатоквартирних будинків. Рекомендовано привести тарифи на утримання та обслуговування житлового фонду до економічно обгрунтованого рівня незалежно від форм управління, запровадити систему оцінки якості надання житлових послуг та впровадити систему моніторингу та санкцій за недотримання встановлених норм.

Перспективи подальших досліджень щодо економіко-правових аспектів інноваційного розвитку житлового фонду України вбачаються у напрацюванні пропозицій щодо обгрунтованості відведення земельної ділянки, на якій розташований ОСББ у власність або оренду співвласниками ОСББ та нарахування обсягів оплати земельного податку.

\section{СПИСОК ВИКОРИСТАНИХ ДЖЕРЕЛ}

1. Проект Житлового кодексу України. [Електронний ресурс]. Режим доступу:http://w1.c1. rada.gov.ua/pls/zweb2/webproc4_2?pf3516=2307\&skl=7

2. Димченко О.В. Житлово-комунальне господарство в реформаційному процесі: аналіз, проектування, управління: [монографія] / О.В. Димченко; Харк. нац. акад. міськ. госп-ва. - Х., 2009. - $356 \mathrm{c}$.

3. Кущ О.Є. Особливості адміністративно-правового регулювання у сфері управління житлово-комунальним господарством України / О.Є. Кущ // Право і суспільство. — 2017. — № 3. C. $134-140$.

4. Про приватизацію державного житлового фонду [закон України] від 19.06.1992 р. № 2482-XII [Електронний ресурс]. - Режим доступу до закону: http://zakon1.rada.gov.ua/laws/show/про приватизацію державного житлового фонду.

5. Господарський кодекс України. [Електронний ресурс] - Режим доступу до: http://zakon. rada.gov.ua/

6. Про житлово-комунальні послуги: Закон України від 07.06.2018 № 2454-VIII. [Електронний ресурс] — Режим доступу до: http://zakon.rada.gov.ua/

7. Податковий кодекс України від 02.12.2010 № 2755-VI. [Електронний ресурс] - Режим доступу до: http://zakon.rada.gov.ua/

8. Конституція України. - [Електронний ресурс] - Режим доступу до: http://zakon3.rada.gov. ua/laws/show/254\%D0\%BA/96-\%D0\%B2\%D1\%80/print

9. Про затвердження переліку нежитлових будівель комунальної власності територіальної громади міста Києва: Рішення Київської міської ради від 29.11.2001 № 151/1585 - [Електронний ресурс] — Режим доступу до: http://kmr.ligazakon.ua/SITE2/1_docki2.nsf/alldocWWW/3B CA3B9E125E7E37C22573C0004BCD95?OpenDocument

10. Про формування комунальної власності територіальних громад районів м. Києва: Рішення Київської міської ради від 27.12.2001 № 208/1642. - [Електронний ресурс] - Режим доступу до: http://kmr.ligazakon.ua/SITE2/1_docki2.nsf/alldocWWW/EAD99B56B9620FCAC22573C00053 E8A4?OpenDocument

11. Про об’єднання співвласників багатоквартирного будинку: Закон України. - [Електронний ресурс] — Режим доступу до: http://zakon3.rada.gov.ua/laws/show/2866-14 
12. Постанова Кабінету Міністрів України № 1521 від 11 жовтня 2002 року Про реалізацію Закону України «Про об'єднання співвласників багатоквартирного будинку». - [Електронний pecypc] - Режим доступу до: http://zakon3.rada.gov.ua/laws/show/1521-2002-\%D0\%BF

13. Цивільний кодекс України від 16.01.2003 № 435-IV — [Електронний ресурс] — Режим доступу до: http://zakon3.rada.gov.ua/laws/show/435-15/print

14. Про особливості здійснення права власності в багатоквартирному будинку: Закон України. - [Електронний ресурс] - Режим доступу до: http://zakon3.rada.gov.ua/laws/show/417-19 15. Про місцеве самоврядування в Україні: Закон України від 21.05.1997 № 280/97-ВР [Електронний ресурс] — Режим доступу до: http://zakon2.rada.gov.ua/laws/show/280/97$\% \mathrm{D} 0 \% \mathrm{~B} 2 \% \mathrm{D} 1 \% 80 /$ page $2 /$ print

16. Про затвердження Положення про співфінансування реконструкції, реставрації, проведення капітальних ремонтів, технічного переоснащення спільного майна у багатоквартирних будинках міста Києва: Рішення Київської міської ради № 780/1784 від 22 грудня 2016 р. [Електронний ресурс] - Режим доступу до: http://kmr.ligazakon.ua/SITE2/1_docki2.nsf/alldocW WW/78805654CC396F16C225809F006DF7A8?OpenDocument

17. Земельний кодекс України від 25.10.2001 № 2768-III — [Електронний ресурс] — Режим доступу до: http://zakon3.rada.gov.ua/laws/show/2768-14/print

18. Про програму економічного і соціального розвитку м. Києва на 2018-2020 рр.: Рішення Київської міської ради № 1042/4049 від 21 грудня 2017 р. // Хрещатик. — № 138 (5051) — 30.12.2017. 19. Офіційний сайт Державної служби статистики України. Статистична інформація. - [Електронний ресурс] - Режим доступу до: www.ukrstat.gov.ua.

20. Лойко В.В., Маляр С.А. Система ефективного управління житловими об'єктами міста Києва [Електронний ресурс]. Ефективна економіка, 2018. № 7. Режим доступу: www.economy. nayka.com.ua/

\title{
ЭКОНОМИКО-ПРАВОВЫЕ АСПЕКТЫ ИННОВАЦИОННОГО РАЗВИТИЯ ЖИЛИЩНОГО ФОНДА УКРАИНЫ
}

\section{Лойко Валерия Викторовна,}

доктор экономических наук, дочент, профессор кафедры финансов и экономики,

Киевский университет имени Бориса Гринченко,

м. Киев, Украина

ORCID iD 0000-0003-3248-1585

e-mail:v.loiko@kubg.edu.ua

\author{
Маляр Станислав Анатолиевич, \\ соискатель степени магистр, \\ Киевский университет имени Бориса Гринченко, \\ м. Киев, Украина \\ e-mail: st.malyar@gmail.com
}

Аннотация. В статье рассмотрены экономико-правовые аспекты инновационного развития жилищного фонда Украины в условиях евроинтеграционного развития экономики Украины. Современный прочесс реформирования жилищного фонда Украины связан с созданием объединений совладельцев многоквартирных домов (ОСМД), которые являются неприбыльными организациями и действуют в рамках, определенных законодательством Украины. В настоящее время конкретный перечень субъектов управления жилищным фондом является отсутствующим. По проведенному анализу нормативно-законодательных актов, регулирующих отношения в сфере жилищного хозяйства, можно выделить следующие субъекты хозяйствования: собственник жилого дома или жилого комплекса, совладелец, многоквартирного дома, объединения совладельцев многоквартирного дома, жилищно-коммунальные предприятия, управляющий, исполнитель коммунальной услуги, потребитель, исполнитель. Среди участников отношений в сфере предоставления услуг по управлению жильем особо следует выделить таких субъектов, как потребитель, производитель и исполнитель жилищно-коммунальных услуг. Совладельцы многоквартирного дома могут осуществлять управление жилищным фондом самостоятельно или непосредственно принимая определенные решения на собрании. Процесс управления жилищным фондом характеризуется наличием иерархии уровней управления и многофункциональностью. Обзор в хро- 
нологической последовательности изменения в законодательных и нормативных актах Украины по управлению объектами жилищного фонда позволил выявить, что на эффективность управления объектами жилищного фонда влияет несовершенство нормативно-правовой базы Украины. Современное экономическое государственное регулировании жилищно-коммунальной сферы осуществляется за счет налоговой, инвестиционной, бюджетной, ценовой политики и ченового регулирования. Процесс управления жилищным фондом, в том числе ОСМД, требует анализа методов управления, применяемых в настоящее время, и наработки опыта по применению инновачионных методов, которые обеспечат достаточный уровень управленческой безопасности. Выделены факторы обеспечения управленческой безопасности жилищной среры. Определена необходимость в увеличении объемов частно-государственного софинансирования программ реконструкции, реставрации, проведения капитальных ремонтов, технического перевооружения общего имущества в многоквартирных домах и реализации энергоэффективных мероприятий в жилых домах городов и сел Украины.

Ключевые слова: Украина, жилищный фонд, состояние, развитие, инновации, законодательство, регулирование, нормативно-правовые акты, эффективность.

\title{
ECONOMIC AND LEGAL ASPECTS OF INNOVATIVE DEVELOPMENT OF HOUSING STOCK OF UKRAINE
}

\section{Valeryia Loiko,}

DSC (Economics), Professor of the Finance and Economics Department, Borys Grinchenko Kyiv University

ORCID iD 0000-0003-3248-1585

e-mail:v.loiko@kubg.edu.ua

\section{Stanyslav Maliar,}

graduate degree candidate

Kiev Borys Grinchenko University,

Kiev, Ukraine

e-mail: st.malyar@gmail.com

\begin{abstract}
The article deals with the economic and legal aspects of the innovative development of the housing stock of Ukraine in conditions of European integration of Ukraine's economy. The current process of reforming the housing stock of Ukraine is connected with the creation of associations of coowners of multi-apartment buildings ( $A C M H s$ ), which are non-profit organizations that operate within the framework defined by the legislation of Ukraine. At present a specific list of housing management entities isn 't available. According to the analysis of legislative acts regulating relations in the sphere of housing, the following business entities can be singled out: the owner of a residential building or residential complex, the co-owner of the apartment building, the association of co-owners of an apartment building, a housing and services enterprise, a manager, a communal services provider, a consumer, an administrant. Among the participants in the provision of services in the sphere of housing management such entities should be distinguished as the consumer, the manufacturer and the administrant of housing and communal services. Co-owners of an apartment building can carry out management of the housing stock indepedently or by taking certain collegial decisions at the meetings. Process of housing management is characterized by the involvement of a hierarchy of management levels and multifunctionality. To have summarized in chronological order the changes in legislative and normative acts of Ukraine regarding the management of housing stock allowed us to establish that the effectiveness of the management of the entities of the housing stock is affected by the imperfection of the legal and regulatory framework of Ukraine. Contemporary economic state regulation of housing and communal sphere is carried out at the expense of tax, investment, budget, pricing policy and price regulation. Housing stock management process, in particular $\mathrm{ACMHs}$, requires analysis of current management methods and accumulation of experience in applying innovative methods that will provide a sufficient level of managerial security. Highlighted are the factors for ensuring managerial security of housing sphere. There is the need to increase the amount of privategovernment co-financing of programs for reconstruction, restoration, major repairs, technical reequipment of joint property in multi-apartment buildings and implementation of measures of energy efficiency in residential buildings of cities and villages of Ukraine
\end{abstract}

Key words: Ukraine, housing stock, state, development, innovations, legislation, regulation, legal acts, efficiency. 


\section{REFERENCES (TRANSLATED AND TRANSLITERATED)}

1. Project of the Housing Code of Ukraine. (2009, March 17). Retrieved November 4, 2018, from http://w1.c1.rada.gov.ua/pls/zweb2/webproc4_2?pf3516=2307\&skl=7

2. Dymchenko O. (2009). Housing and communal economy in the reformation process: Analysis, design, management. Manuscript submitted for publication, Kharkiv National Academy of Municipal Economy, Kharkiv.

3. Kushch O. (2017). Features of administrative and legal regulation in the sphere of housing and communal services management of Ukraine. Law and Society, 134-140.

4. On the Privatization of the State Housing Fund [Law of Ukraine]. (1992, June 19). Retrieved November 1, 2018, from https://zakon1.rada.gov.ua/laws/show/про приватизацію державного житлового фонду

5. Economic Code of Ukraine. (2003, January 16). Retrieved October 28, 2018, from https://zakon. rada.gov.ua/laws/main/436-15

6. On housing and communal services. (2018, June 7). Retrieved September 21, 2018, from https:// zakon.rada.gov.ua/laws/show/2189-19

7. The Tax Code. (2010, December 2). Retrieved November 22, 2018, from https://zakon.rada.gov.ua/ laws/main/2755-17

8. The Constitution of Ukraine. (1996, June 28). Retrieved November 18, 2018, from http://zakon3. rada.gov.ua/laws/show/254к/96-вр/print

9. On approval of the list of non-residential buildings of communal ownership of the territorial community of the city of Kyiv: Decision of the Kyiv City Council. (2001, November 29). Retrieved November 26, 2018, from http://kmr.ligazakon.ua/SITE2/1_docki2.nsf/alldocWWW/3BCA3B9E125 E7E37C22573C0004BCD95?OpenDocument

10. About the formation of communal ownership of territorial communities of the districts of Kyiv. (2001, November 8). Retrieved October 10, 2018, from http://kmr.ligazakon.ua/SITE2/1_docki2.nsf/ alldocWWW/EAD99B56B9620FCAC22573C00053E8A4?OpenDocument

11. On the association of co-owners of a multi-apartment building. (1996, June 28). Retrieved November 25, 2018, from http://zakon3.rada.gov.ua/laws/show/2866-14

12. Resolution of the Cabinet of Ministers of Ukraine No. 1521 dated October 11, 2002 on the implementation of the Law of Ukraine "On the Association of Co-Owners of a MultiApartment Building". (2001, October 11). Retrieved November 1, 2018, from https://zakon.rada.gov. ua/laws/show/1521-2002-п

13. Civil Code of Ukraine. (2003, January 16). Retrieved September 20, 2018, from https://zakon3. rada.gov.ua/laws/show/435-15/print

14. About the peculiarities of realization of the property right in an apartment building. (2015, May 14). Retrieved September 10, 2018, from https://zakon3.rada.gov.ua/laws/show/417-19

15. On Local Self-Government in Ukraine. (1997, June 21). Retrieved September 19, 2018, from http://zakon2.rada.gov.ua/laws/show/280/97-вp/page2/print

16. About approval of the Regulation on co-financing of reconstruction, restoration, capital repairs, technical re-equipment of common property in multi-apartment buildings of the city of Kyiv. (2017, March 17). Retrieved November 6, 2018, from http://kmr.ligazakon.ua/SITE2/1_docki2.nsf/alldocW WW/78805654CC396F16C225809F006DF7A8?OpenDocument

17. Land Code of Ukraine dated 25.10.2001 No. 2768-II. (2005, October 25). Retrieved November 3, 2018, from http://zakon3.rada.gov.ua/laws/show/2768-14/print

18. About the Program of Economic and Social Development of Kyiv in 2018-2020: Decision of the Kyiv City Council No. 1042/4049 of December 21, 2017. (2017, December 30). Khreshchatyk. Retrieved October 2, 2018.

19. Official site of the State Statistics Service of Ukraine. Statistical information. (n.d.). Retrieved September 5, 2018, from www.ukrstat.gov.ua

20. Loiko V.V., Malyar S.A. System of effective management of housing objects of the city of Kyiv. (2018). Retrieved November 1, 2018, from http://www.economy.nayka.com.ua/?op=1\&z=6446 